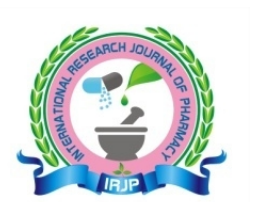

INTERNATIONAL RESEARCH JOURNAL OF PHARMACY

www.irjponline.com

ISSN $2230-8407$

\title{
Research Article \\ DEVELOPMENT AND VALIDATION OF STABILITY-INDICATING HPLC METHOD FOR DETERMINATION OF BOCEPREVIR
}

Mrinalini C. Damle *, Sunny R. Salunke

AISSMS College of Pharmacy, Kennedy Road, Near RTO, Pune, Maharashtra, India

*Corresponding Author Email: mcdamle@rediffmail.com

Article Received on: 17/06/16 Revised on: 20/07/16 Approved for publication: 26/07/16

DOI: $10.7897 / 2230-8407.07895$

\begin{abstract}
A simple and rapid stability indicating HPLC method for Boceprevir was successfully developed and was validated. This method is based on HPLC separation followed by UV detection at $215 \mathrm{~nm}$. HPLC method was developed on a symmetry Thermo $\mathrm{C}_{18} \quad(250 \mathrm{x} 4.6 \mathrm{~mm}$ i.d, $5 \mu \mathrm{m})$ column ( $\mathrm{sr}$ no. 0860953Q) with a mobile phase consisting of methanol : 10mM di-sodium hydrogen phosphate buffer(pH 2.5):triethylamine $90: 10: 0.05 \% \mathrm{v} / \mathrm{v} / \mathrm{v}$, pumped at $1.0 \mathrm{ml}$ min-1 flow rate. The $\mathrm{pH}$ of buffer was adjusted to 2.5 with ortho phosphoric acid. The column was maintained at ambient temperature. The eluted compound was detected by using PDA detector. Boceprevir eluted at $3.33 \pm 0.2$ min. Stress degradation study shows that sample degraded with acid and base hydrolysis, under oxidation, thermal and photolytic stress conditions. The method was validated in accordance with requirement of $\mathrm{ICH}$ guidelines.
\end{abstract}

Keywords: Boceprevir, HPLC, Forced degradation, Validation.

\section{INTRODUCTION}

Boceprevir is a direct acting protease inhibitor for the treatment of hepatitis $C^{1}$. Chemical name ofboceprevir is $3-\{[(1 R, 2 S, 5 S)-$ $3-[(2 \mathrm{~S}) \quad-\quad 2-[($ tert-butylcarbamoyl)amino $]-3,3-$ dimethylbutanoyl] - 6,6-dimethyl-3azabicyclo[3.1.0]hexan - 2 yl]formamido $-4-$ cyclobutyl $-2-$ oxobutanamide. $^{1}$ Chemical structure of Boceprevir was shown in Figure 1. Boceprevir contains 5 chiral centres, four of them have a fixed stereochemical configuration controlled during the synthesis and the last one is obtained as a mixture of 2 configurations $\mathrm{R}$ and $\mathrm{S}$. Thus, Boceprevir is manufactured as an equal mixture of two diastereoisomers in an approximate amount of $1: 1 .^{2}$ A thorough literature search indicate that there are some methods reports for estimation of boceprevir by HPLC $^{3}$ and UPLC-MS/MS ${ }^{4,5}$ methods. There is no Stability-Indicating HPLC Method (SIM) have been reported for Boceprevir. The objective of current work was to develop Stability-Indicating HPLC Method (SIM) as per ICH Q1A (R2) guidelines. It was aimed to establish inherent stability of the Boceprevir through stress studies under a variety of stress conditions and to develop a validated Stability-Indicating Assay method.

\section{MATERIALS AND METHODS}

\section{Chemicals and reagents}

Working standard of Boceprevir was kindly supplied by Mylan Laborotories Ltd. (Hyderabad) India. Methanol (HPLC grade), sodium hydrogen phosphate, orthophosphoric acid, triethylamine were purchased from Merck specialties Pvt. Ltd. (Mumbai, India).

\section{Instruments}

Quantitative HPLC was performed using isocratic high performance liquid chromatography (Jasco HPLC system) with a LC-PU 2080 Plus pump, manual injector with loop volume of $20 \mu \mathrm{l}$ (Rheodyne), programmable MD 2010 PDA detector and HiQsil $\mathrm{C}_{18}(150 \times 4.6 \mathrm{~mm}$ i.d, $5 \mu \mathrm{m})$. The HPLC system was equipped with "Borwin- PDA software (version1.5). An electronic balance (Shimadzu AY-120), UV-Visible (Jasco model V-550) spectrophotometer, Elga Lab water (PURELAB UHQ-II) water purification system were used in this study.

\section{Optimized chromatographic conditions}

The mobile phase consisting of Methanol: $10 \mathrm{mM}$ sodium dihydrogen phosphate buffer ( $\mathrm{pH} 2.5$ ): triethylamine in the ratio of $(90: 10: 0.5) \% \mathrm{v} / \mathrm{v} / \mathrm{v}$. It was then filtered through $0.45 \mu$ membrane filter paper using vacuum filtration assembly and then sonicated on ultrasonic water bath for $15 \mathrm{~min}$. The flow rate of mobile phase was maintained at $1 \mathrm{ml} / \mathrm{min}$ and the column and the HPLC systems were kept in ambient temperature.

\section{Preparation of standard Stock Solution}

Standard stock solution of Boceprevir was prepared by dissolving $10 \mathrm{mg}$ of drug in $10 \mathrm{ml}$ of methanol to get concentration of $1000 \mu \mathrm{g} / \mathrm{ml}$. Further dilution was made in methanol to get final concentration range of Boceprevir $50,100,150,200,250 \mu \mathrm{g} / \mathrm{ml}$.

\section{Preparation of Buffer}

Preparetion of buffer procedure in IP Dissolve $90 \mathrm{mg}$ of di sodium hydrogen phosphate in $100 \mathrm{ml}$ of HPLC grade water and adjust the $\mathrm{pH} 2.5$ with $10 \%$ orthophosphoric acid. 


\section{Preparation of $1 \mathrm{~N}$ Hydrochloric acid solution}

Hydrochloric acid (1N) was prepared by diluting $0.85 \mathrm{ml}$ of concentrated hydrochloric acid solution with methanol up to 10 $\mathrm{ml}$.

\section{Preparation of 0.1 N Sodium hydroxide solution}

Sodium hydroxide powder (40mg) was dissolved in methanol in $10 \mathrm{ml}$ volumetric flask the volume was made up with methanol to get $0.1 \mathrm{~N}$ sodium hydroxide solution.

\section{Preparation of $3 \% \mathrm{v} / \mathrm{v}$ Hydrogen peroxide solution}

Hydrogen peroxide $(3 \% \mathrm{v} / \mathrm{v})$ was prepared by appropriately diluting $1 \mathrm{ml}$ of $30 \% \mathrm{v} / \mathrm{v}$ hydrogen peroxide to $10 \mathrm{ml}$ with methanol.

\section{Selection of Detection Wavelength}

The UV spectrum of Boceprevir $(100 \mu \mathrm{g} / \mathrm{ml})$ solution was obtained over the range of $200-400 \mathrm{~nm}$. It was observed that drug showed considerable absorbance at $215 \mathrm{~nm}$. So, wavelength $215 \mathrm{~nm}$ was selected as the wavelength for detection was shown in Figure 2.

Table 1: System suitability parameter

\begin{tabular}{|c|c|c|c|c|c|}
\hline Name & RT $(\mathbf{m i n})$ & Conc. $(\boldsymbol{\mu g} / \mathbf{m l})$ & Area & Plates & Asymmetry \\
\hline Boceprevir & 3.33 & 150 & 3150023 & 2650.4 & 1.36 \\
\hline
\end{tabular}

Table 2: Data of forced degradation studies of Boceprevir

\begin{tabular}{|c|c|c|c|c|c|}
\hline \multirow[t]{2}{*}{ Sr. No } & \multirow[t]{2}{*}{ Stress conditions/ duration } & \multirow[t]{2}{*}{ \% Recovery } & \multirow{2}{*}{$\begin{array}{l}\text { Rt of degradation } \\
\text { products (min.) }\end{array}$} & \multicolumn{2}{|c|}{ Pear purity } \\
\hline & & & & Peak front & Peak tail \\
\hline 1. & $\begin{array}{c}\text { Acidic hydrolysis / } 1 \mathrm{~N} \mathrm{HCl} \text { reflux } \\
\text { for } 15 \mathrm{~min} .\end{array}$ & 72.81 & 2.7 & 994.1 & 996.3 \\
\hline 2. & $\begin{array}{l}\text { Alkaline hydrolysis } / 0.1 \mathrm{~N} \mathrm{NaOH} / \\
\text { kept at room temperature for } 1 \mathrm{Hr} \text {. }\end{array}$ & 73.41 & $2.9,3.7$ & 992.4 & 994.8 \\
\hline 3. & $\begin{array}{c}\text { Oxidative } / 3 \% \mathrm{v} / \mathrm{v} \mathrm{H}_{2} \mathrm{O}_{2} / \text { kept at } \\
\text { room temperature for } 3 \text { Hours }\end{array}$ & 86.03 & - & 996.8 & 996.5 \\
\hline 4. & $\begin{array}{c}\text { Neutral hydrolysis } / \mathrm{H}_{2} \mathrm{O} \text { reflux for } \\
1 \mathrm{hr}\end{array}$ & 88.03 & - & 994.5 & 995.8 \\
\hline 5. & Dry heat $/ 80^{\circ} \mathrm{C} / 12$ hours & 90.39 & - & 992.9 & 995.3 \\
\hline 6. & $\begin{array}{c}\text { UV light } \\
\text { (200 Watt hours/Square meter) }\end{array}$ & 53.48 & - & 995.7 & 997.1 \\
\hline 7. & $\begin{array}{c}\text { Fluorescence light } \\
(1.2 \text { million lux hours }) .\end{array}$ & 77.18 & - & 993.6 & 995.2 \\
\hline
\end{tabular}

Table 3: Specificity

\begin{tabular}{|c|c|c|}
\hline Drug & Purity tail & Purity front \\
\hline Boceprevir & 993.712 & 996.17 \\
\hline
\end{tabular}

Table 4: Assay of Spiked blend powder

\begin{tabular}{|c|c|c|c|}
\hline Sr. No. & Peak area of Boceprevir & Amount Recovered $(\boldsymbol{\mu g} / \mathbf{m l})$ & \% assay \\
\hline 1 & 3122101 & 153.00 & 102.00 \\
\hline 2 & 3086274 & 151.14 & 100.76 \\
\hline 3 & 3150130 & 154.46 & 102.97 \\
\hline 4 & 3052443 & 149.39 & 99.59 \\
\hline 5 & 3020148 & 147.71 & 98.47 \\
\hline 6 & 3100341 & 151.87 & 101.25 \\
\hline Mean & 3088572.83 & 151.26 & 100.84 \\
\hline SD & 46998.97 & 2.43 & 1.62 \\
\hline \%RSD & 1.52170 & 1.61 & 1.61 \\
\hline
\end{tabular}

Table 5: Recovery studies of Boceprevir

\begin{tabular}{|c|c|c|c|c|c|}
\hline \multirow{2}{*}{ Drug } & $\begin{array}{c}\text { Amount taken } \\
(\boldsymbol{\mu g} / \mathbf{m l})\end{array}$ & $\begin{array}{c}\text { Amount added } \\
(\boldsymbol{\mu g} / \mathbf{m l})\end{array}$ & Total Area found & \% Recovery & \%SD \\
\hline \multirow{3}{*}{ Boceprevir } & 100 & 80 & 3697489.33 & 101.59 & 1.56 \\
\cline { 2 - 6 } & 100 & 100 & 3955648.00 & 98.13 & 1.36 \\
\cline { 2 - 6 } & 100 & 120 & 4418772.66 & 100.13 & 0.73 \\
\hline
\end{tabular}

*Average of three determinations 
Mrinalini C. Damle \& Sunny R. Salunke. Int. Res. J. Pharm. 2016, 7 (8)

Table 6: Intra-day precision study of Boceprevir

\begin{tabular}{|c|c|c|c|c|}
\hline $\begin{array}{c}\text { Concentration } \\
(\mu \mathrm{g} / \mathrm{ml})\end{array}$ & Area & Mean Area & SD & $\%$ RSD \\
\hline \multirow[t]{3}{*}{100} & 2113417 & \multirow{3}{*}{2103596} & \multirow[t]{3}{*}{9379.61} & \multirow[t]{3}{*}{0.44} \\
\hline & 2113417 & & & \\
\hline & 2113417 & & & \\
\hline \multirow[t]{3}{*}{150} & 3140487 & \multirow{3}{*}{3124115} & \multirow[t]{3}{*}{25520.14} & \multirow[t]{3}{*}{0.81} \\
\hline & 3094710 & & & \\
\hline & 3137148 & & & \\
\hline \multirow[t]{3}{*}{200} & 3943482 & \multirow{3}{*}{3932470} & \multirow[t]{3}{*}{36765.40} & \multirow[t]{3}{*}{0.93} \\
\hline & 3891457 & & & \\
\hline & 3962471 & & & \\
\hline
\end{tabular}

Table 7: Inter-day precision of Boceprevir

\begin{tabular}{|c|c|c|c|c|}
\hline $\begin{array}{c}\text { Concentration } \\
(\mu \mathrm{g} / \mathrm{ml})\end{array}$ & Area & Mean Area & SD & $\%$ RSD \\
\hline \multirow[t]{3}{*}{100} & 2134716 & \multirow[t]{3}{*}{2110094.00} & \multirow[t]{3}{*}{32104.98} & \multirow[t]{3}{*}{1.52} \\
\hline & 2073782 & & & \\
\hline & 2121784 & & & \\
\hline \multirow[t]{3}{*}{150} & 3064711 & \multirow[t]{3}{*}{3095309.33} & \multirow[t]{3}{*}{26750.70} & \multirow[t]{3}{*}{0.86} \\
\hline & 3106947 & & & \\
\hline & 3114270 & & & \\
\hline \multirow[t]{3}{*}{200} & 3968120 & \multirow[t]{3}{*}{3934867.33} & \multirow[t]{3}{*}{39403.62} & \multirow[t]{3}{*}{1.00} \\
\hline & 3891346 & & & \\
\hline & 3945136 & & & \\
\hline
\end{tabular}

Table 8: Robustness study

\begin{tabular}{|c|c|c|c|c|c|c|}
\hline \multirow{3}{*}{ Drug } & \multicolumn{4}{|c|}{ \% RSD Found For Robustness Study(peak area) } \\
\cline { 2 - 7 } & \multicolumn{3}{|c|}{$\begin{array}{c}\text { Flow Rate } \\
(\mathbf{1 ~ m / / m i n )}\end{array}$} & \multicolumn{2}{c|}{$\begin{array}{c}\text { pH. of Buffer } \\
\text { (pH 2.5) }\end{array}$} & \multicolumn{2}{c|}{$\begin{array}{c}\text { Mobile phase ratio } \\
\text { (90:10) }\end{array}$} \\
\cline { 2 - 7 } & 0.9 & 1.1 & 2.4 & 2.6 & $89: 91: 0.5$ & $91: 09: 0.5$ \\
\hline Boceprevir & 0.61 & 0.58 & 0.34 & 0.73 & 0.99 & 1.06 \\
\hline
\end{tabular}

Table 9: Summary of validation parameter

\begin{tabular}{|c|c|}
\hline Validation parameters & Boceprevir \\
\hline Linearity Equation & $\mathrm{y}=19270 \mathrm{x}+173614$ \\
(r2) & $\mathrm{r}^{2}=0.9977$ \\
Range & $50-250 \mu \mathrm{g} / \mathrm{ml}$ \\
\hline Precision (\% RSD) & 1.00 \\
Interday & 0.93 \\
\hline Intraday & $\%$ Recovery \\
\hline Accuracy & 101.59 \\
\hline $80 \%$ & 98.13 \\
\hline $100 \%$ & 100.13 \\
\hline $120 \%$ & $3.49 \mu \mathrm{g} / \mathrm{ml}$ \\
\hline Limit of Detection & $10.59 \mu \mathrm{g} / \mathrm{ml}$ \\
\hline Limit of Quantitation & Specific \\
\hline Specificity & Robust \\
\hline Robustness & \\
\hline
\end{tabular}

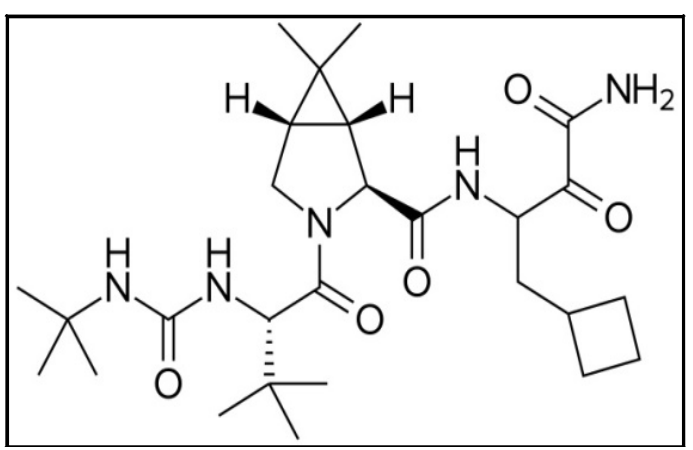

Figure 1: Chemical structure of Boceprevir

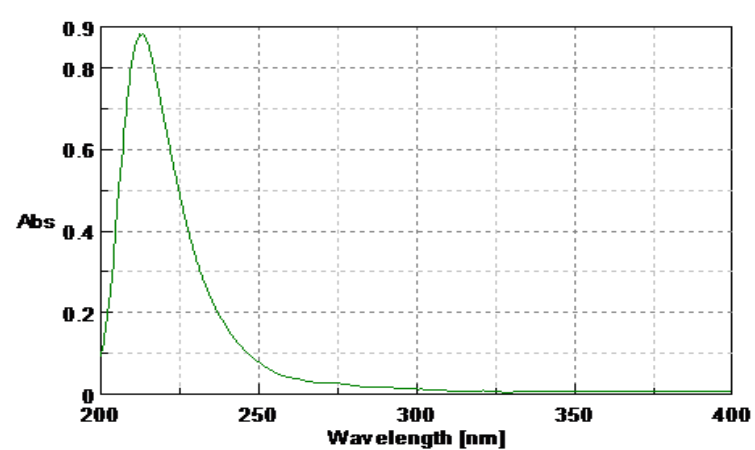

Figure2: UV Spectrum of Boceprevir $(100 \mu \mathrm{g} / \mathrm{ml})$ 


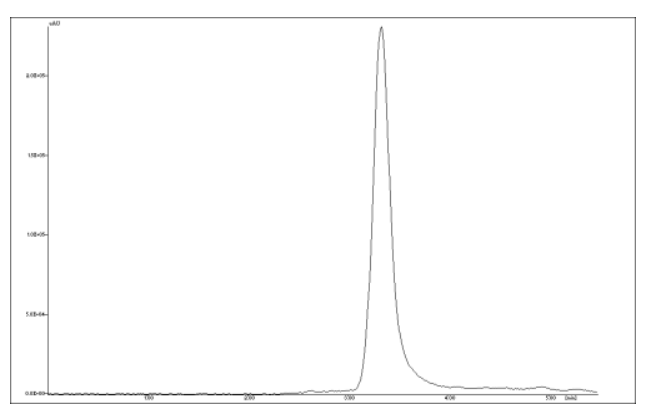

Figure 3: Chromatogram of standard solution of Boceprevir( $\mathrm{RT}=$ $3.33 \pm 0.2 \mathrm{~min})$

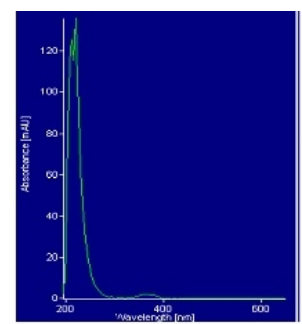

(A)

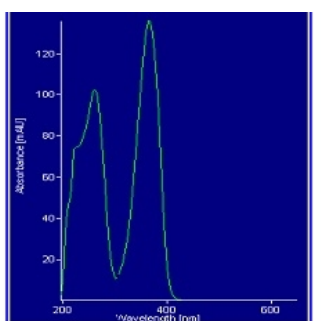

(B)
Figure 5: A) UV spectrum of Boceprevir at RT- 3.33 min., B) UV spectrum of Degradation product at RT- 2.7

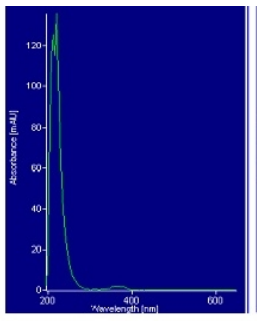

(A)

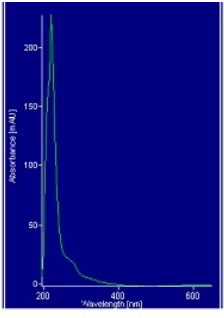

(B)

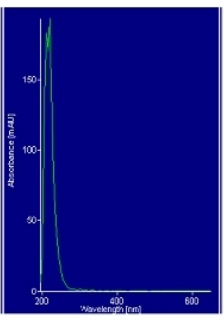

(C)
Figure 7: A) UV spectrum of Boceprevir at RT- 3.33 min., B) UV spectrum of Degradation product at RT- $2.9 \mathrm{~min}$., C) UV spectrum of Degradation product at RT-3.7 min.

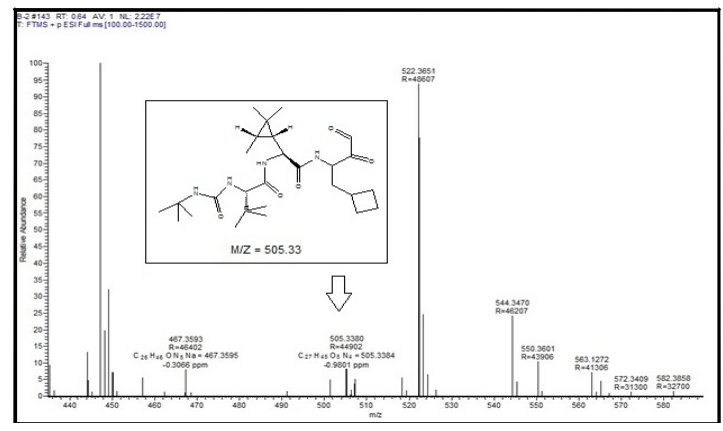

Figure 9: LCMC spectra of alkali degradation product

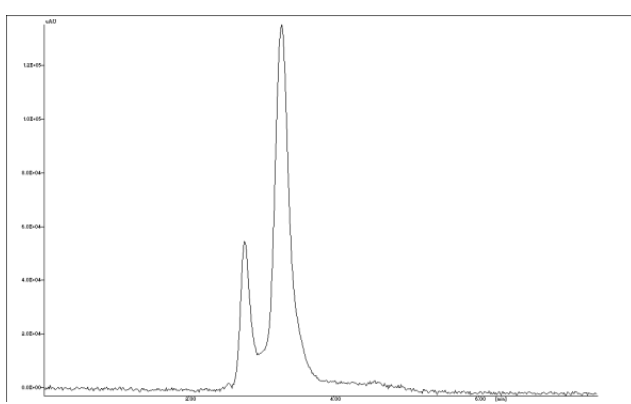

Figure 4: Chromatogram obtained from sample subjected to acid degradation with degradation product RT $2.7 \mathrm{~min}(150 \mu \mathrm{g} / \mathrm{ml})$

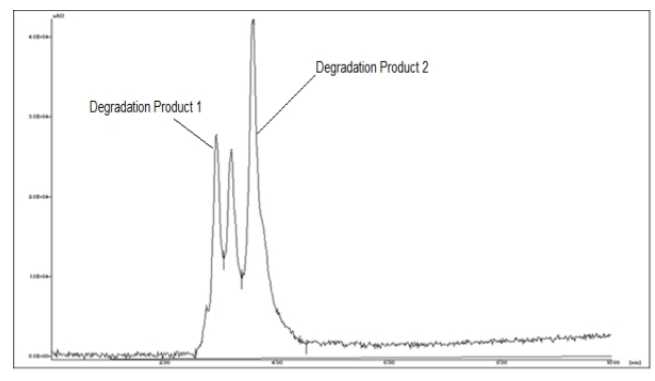

Figure 6: Chromatogram obtained from sample subjected to Base degradation for overnight with degradation product RT 2.9 and 3.7 $\min (150 \mu \mathrm{g} / \mathrm{ml})$

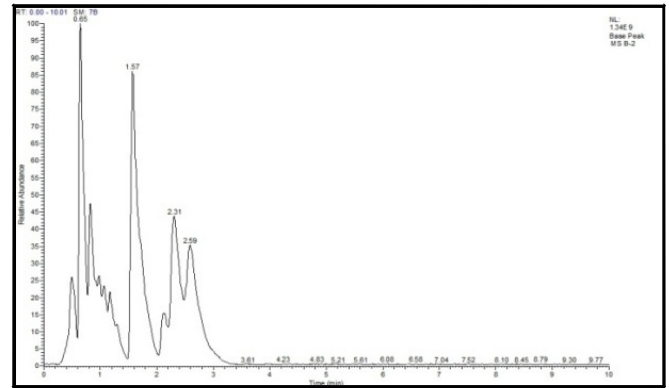

Figure 8: Chromatogram obtained from base induced degradation product

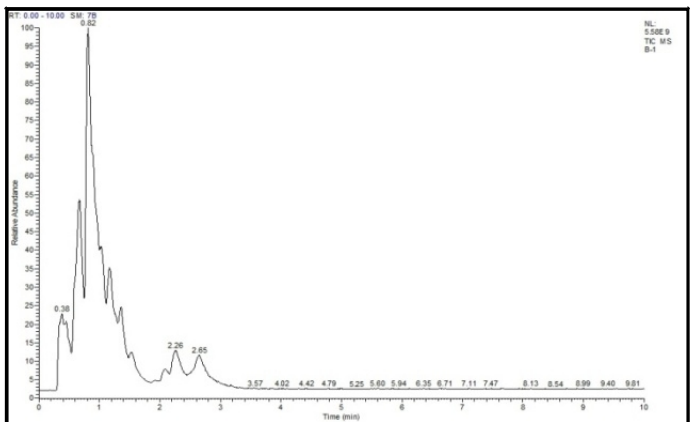

Figure 10: Chromatogram obtained from sample subjected to acid degradation 


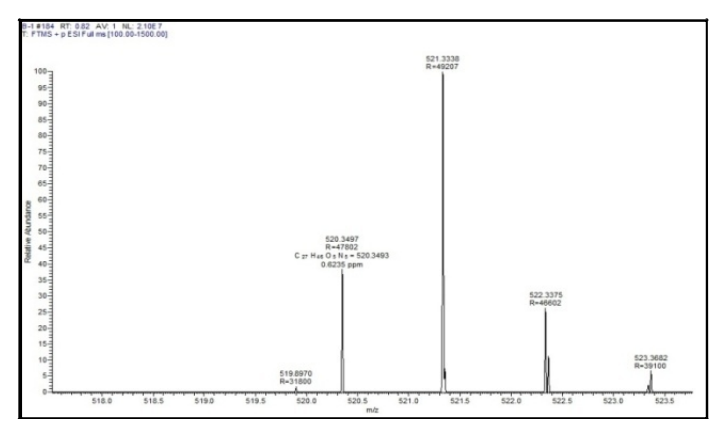

Figure 11: LCMC spectra of acid reflux degradation product

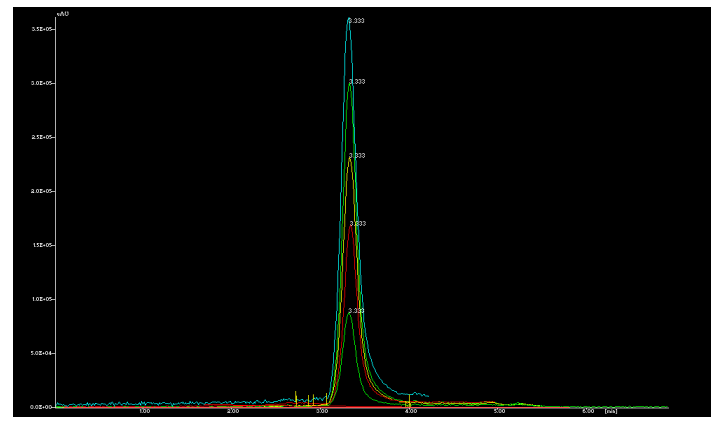

Figure 13: Chromatogram of linearity of Boceprevir $(50-250 \mu \mathrm{g} / \mathrm{ml})$

\section{RESULTS AND DISCUSSION}

\section{Selection of mobile phase}

The standard solution of Boceprevir $(150 \mu \mathrm{g} / \mathrm{ml})$ was injected into the HPLC system and run in different solvent systems. Different mobile phases like acetonitrile and water, methanol and water, acetonitrile and phosphate buffer, methanol and phosphate buffer in varying proportion of mobile phase components, varying conditions of $\mathrm{pH}$ were tried in order to obtain the desired system suitability parameters for the Boceprevir. After several trials, methanol, $10 \mathrm{mM}$ disodium hydrogen phosphate $\mathrm{pH} 2.5$ and triethylaminein the ratio of 90 : $10: 0.5 \% \mathrm{v} / \mathrm{v} / \mathrm{v}$ was chosen as the mobile phase, which gave good resolution and acceptable peak parameters.

\section{Chromatogram and system suitability parameter of drug}

The column was equilibrated with the mobile phase (indicated by constant back pressure at desired flow rate). Working standard solution of drug $150 \mu \mathrm{g} / \mathrm{ml}$ was injected into the system shown in Figure 3. The retention time for the drug was found to be:3.33 $\pm 0.2 \mathrm{~min}$. System suitability parameters of Boceprevir are summarized in Table 1.

\section{Stress degradation studies of bulk drug}

Stress degradation studies were carried under condition of acid, base, neutral hydrolysis, oxidation, dry heat and photolysis as per ICH Q1A (R2) and Q1B. For each study, two samples were prepared: the blank subjected to stress in the same manner as the drug solution and working standard solution of Boceprevir was subjected to stress condition. Dry heat and photolytic degradation were carried out in solid state. ${ }^{6-7}$

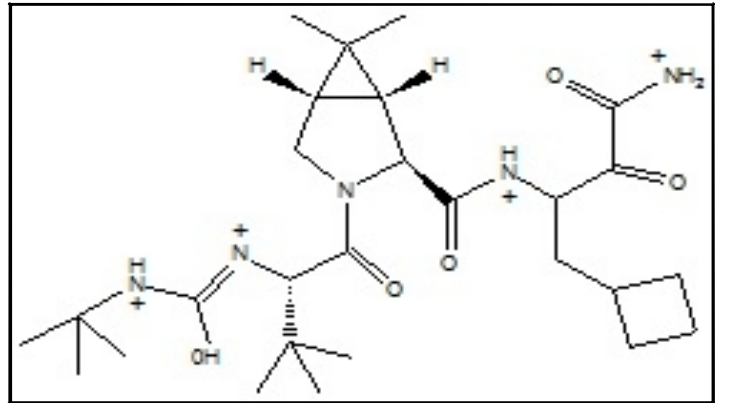

Figure 12: formation of quaternary compound

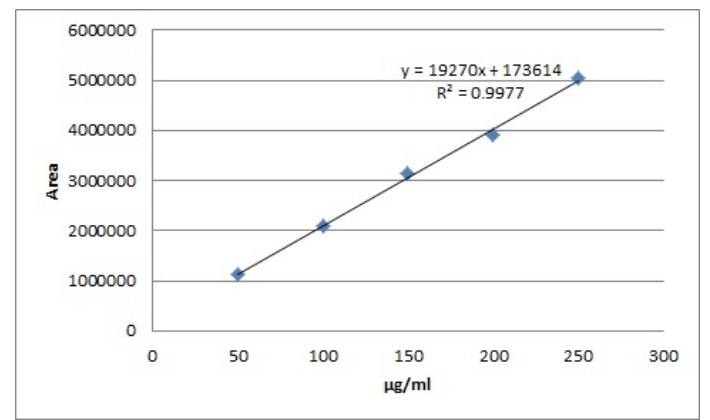

Figure 14: Calibration curve for Boceprevir

\section{Acid hydrolysis}

$5 \mathrm{ml}$ working standard solution of Boceprevir $(10000 \mu \mathrm{g} / \mathrm{ml})$ was mixed with $5 \mathrm{ml}$ of $1 \mathrm{~N}$ methanolic hydrochloric acid $(\mathrm{HCl})$ and $40 \mathrm{ml}$ of methanol. Solution was refluxed for $15 \mathrm{~min}$. The solution was neutralized with $5 \mathrm{ml}$ of Sodium Hydroxide $(\mathrm{NaOH})$ solution. Final solution $(150 \mu \mathrm{g} / \mathrm{ml})$ was injected.

After acid hydrolysis, $72.81 \%$ Boceprevir was recovered with the product of degradation at RT 2.7 min was shown in Figure 4 and 5 .

\section{Base hydrolysis}

Initially trials were conducted using $1 \mathrm{~N} \mathrm{NaOH}$ by keeping the sample solution for 24 hours. It was observed that drug gets degraded with two peak of degradation products RT 2.9 and 3.7 $\min (150 \mu \mathrm{g} / \mathrm{ml})$ was shown in Figure 6 and 7 . Base induced degradation was performed by adding $1 \mathrm{ml}$ of $0.1 \mathrm{~N}$ sodium hydroxide $(\mathrm{NaOH})$ to volumetric flask containing $1 \mathrm{ml}$ of Boceprevir standard solution $(10000 \mu \mathrm{g} / \mathrm{ml})$. The volume was made up to $10 \mathrm{ml}$ with methanol kept at room temperature for 1 Hour. The solution was neutralized with $0.1 \mathrm{~N}$ of Hydrochloric acid $(\mathrm{HCl})$ solution. Final solution $(150 \mu \mathrm{g} / \mathrm{ml})$ was injected. After alkaline hydrolysis, $73.41 \%$ Boceprevir was recovered with no peak of degradation.

\section{Neutral Hydrolysis}

$5 \mathrm{ml}$ working standard solution of Boceprevir $(10000 \mu \mathrm{g} / \mathrm{ml})$ was mixed with $5 \mathrm{ml}$ water and $40 \mathrm{ml}$ of methanol. Solution was refluxed for $15 \mathrm{~min}$. Final solution $(150 \mu \mathrm{g} / \mathrm{ml})$ was injected. After neutral hydrolysis, $88.03 \%$ Boceprevir was recovered with no peak of degradation. 


\section{Oxidative Hydrolysis}

Oxidative degradation was performed by adding $1 \mathrm{ml}$ of Hydrogen peroxide $\left(\mathrm{H}_{2} \mathrm{O}_{2}, 3 \% \mathrm{v} / \mathrm{v}\right)$ to volumetric flask containing $1 \mathrm{ml}$ of Boceprevir standard solution $(10000 \mu \mathrm{g} / \mathrm{ml})$. The volume was made up to $10 \mathrm{ml}$ with methanol \&kept at room temperature for 3 Hour.

After oxidative hydrolysis, $86.03 \%$ Boceprevir was recovered with no peak of degradation.

\section{Degradation under dry heat}

Dry heat study was performed by exposing Boceprevirin oven $\left(80^{\circ} \mathrm{C}\right)$ for a period of 12 hours. A sample was withdrawn after 12 hours, weighed and dissolved in methanol to get solution of $1000 \mu \mathrm{g} / \mathrm{ml}$ and further dilutions were made with methanol to get final concentration $(150 \mu \mathrm{g} / \mathrm{ml})$

After the dry heat degradation, $90.39 \%$ Boceprevir was recovered with no peaks of degradation.

\section{Photo-degradation studies ${ }^{8}$}

Photolytic degradation studies were carried out by exposure of drug to UV light up to 200 watt hours /square meter and subsequently to fluorescence light illumination not less than 1.2 million lux hours. Sample was weighed, dissolved in methanol to get concentration of $1000 \mu \mathrm{g} / \mathrm{ml}$. and further dilutions were made with methanol to get final concentration $(150 \mu \mathrm{g} / \mathrm{ml})$

After the photo degradation study under UV light $53.48 \%$ and Fluorescence light $77.18 \%$ Boceprevir was recovered with no peak of degradation.

\section{Characterization of degradation product by LCMS}

\section{LCMS conditions}

For the identification of degradation product during forced degradation study (acid and alkali stress conditions) LC-MS system was used. Column: Thermo scientific-50*2.1 micron size was used as stationary phase. The flow rate was $350 \mu 1 / \mathrm{min}$ and the column temperature was maintained at $23^{\circ} \mathrm{C}$. Mobile phase contains a mixture of acetonitrile: water $(50: 50 \mathrm{v} / \mathrm{v})$. The analysis was performed in positive electrospray ionization mode.

\section{Alkali treatment \\ Probable Reaction Mechanism \\ A) Cleavage of heterocyclic ring. \\ B) alkaline hydrolysis of amide.}

From LC-MS data the degradation product which was observed in alkali degradation sample shows protonated molecular ion at $\mathrm{m} / \mathrm{z}=505.33$. The possible probable structure of the degradation product $(\mathrm{m} / \mathrm{z}=505.33)$ was shown in Figure 8 and 9.

\section{Acid treatment}

From LC-MS data the degradation product which was observed in acid degradation sample shows protonated molecular ions at $\mathrm{m} / \mathrm{z}=520.34,522.33,521.33$. The possible probable structure of the degradation product $(\mathrm{m} / \mathrm{z}=520.34,522.33,521.33$.) was shown in Figure 10 and 11

\section{Probable Reaction Mechanism}

A) Tautomerism.

B) Formation of quaternary compound.

Probable structure was shown in Figure 12

The forced degradation studies data is summarized in Table 2 .
Method Validation

The method was validated for various parameter in accordance with ICH guidelines. ${ }^{9}$

\section{Specificity}

The specificity of the method was ascertained by peak purity profiling studies. The peak purity values were found to be more than 990, indicating the non-interference of any other peak of degradation product or impurity was shown in Table 3.

\section{Linearity}

Linearity was tested for the range of concentrations 50$250 \mu \mathrm{g} / \mathrm{ml}$. Each sample in five replicates was analyzed and peak areas were recorded. The response factors were plotted against the corresponding concentrations of Boceprevir obtaine the calibration curve. Figure 10 and 11 represents the linearity and calibration curve for Boceprevir respectively.

\section{Range}

Boceprevir: The range was found to be $50-250 \mu \mathrm{g} / \mathrm{ml}$

\section{Assay}

Marketed sample was not available in India therefore spiked blend was used. Accurately weighed quantity of Boceprevir was mixed with blank blend (BB) containing starch and lactose. Spiked blend (SB) was assayed and used for accuracy studies. To determine accuracy, $200 \mathrm{mg}$ blank blend and $800 \mathrm{mg}$ drug were mixed properly and finally $1000 \mathrm{mg}$ SB were prepared. Blend equivalent to $10 \mathrm{mg}$ of drug was transferred to $10 \mathrm{~mL}$ volumetric flask and was diluted with methanol, sonicated for $10 \mathrm{~min}$ and volume made to $10 \mathrm{~mL}(1000 \mu \mathrm{g} / \mathrm{mL}$ Further dilution was made in methanol to get final concentration of Boceprevir $150 \mu \mathrm{g} / \mathrm{ml}$. The results obtained are shown in Table 4.

\section{Accuracy}

To check accuracy of the method, recovery studies were carried out by adding standard drug to Blend (Excipients) at three different levels $80 \%, 100 \%$ and $120 \%$. Basic concentration of sample chosen was $100 \mu \mathrm{g} / \mathrm{ml}$ of standard. These solutions were injected into HPLC system in triplicate to obtain the chromatogram. The drug concentrations were calculated by using linearity equation of Boceprevir. The results obtained is shown in Table 5.

\section{Precision}

The precision of the method was demonstrated by intra-day and inter-day studies. In the intra-day studies, 3 replicates of 3 standard solutions $(100,150$ and $200 \mu \mathrm{g} / \mathrm{ml})$ were analyzed in a same day and percentage RSD was calculated (Table 6). For the inter-day variation studies, 9 replicates of 3 standard solutions $(100,150$ and $200 \mu \mathrm{g} / \mathrm{ml})$ were analyzed on 3 consecutive days and percentage RSD was calculated and shown in Table 6 and 7.

\section{Limit of detection (LOD) and Limit of quantitation (LOQ)}

LOD and LOQ were calculated as $3.3 \mathrm{\sigma} / \mathrm{S}$ and $10 \mathrm{\sigma} / \mathrm{S}$, respectively; where $\sigma$ is the standard deviation of the response at lowest concentration in range and $\mathrm{S}$ is the slope of the calibration plot. The LOD and LOQ were found to be $3.49 \mu \mathrm{g} /$ $\mathrm{ml}$ and $10.59 \mu \mathrm{g} / \mathrm{ml}$ respectively.

\section{Robustness Studies}

Robustness of the method was determined by carrying out the analysis under conditions during which flow rate, Concentration (Strength) of buffer, mobile phase ratio were altered and the effects on the peak area were noted and was shown in Table 8. 
Summary of validation parameter

Summary of validation parameter was shown in Table 9.

\section{CONCLUSION}

The developed method is stability indicating, since the drug peak was found to be pure as confirmed by peak purity profiling study. This proves that there is no interference of degradation product in analytical peak. The degradation product obtained under hydrolytic conditions are well resolved. The method is specific, accurate, precise, and robust and can be used for routine quality control as well as assessing the stability of Boceprevir.

\section{ACKNOWLEDGEMENT}

The authors are thankful to the Principal and management of AISSMS college of Pharmacy, Pune for providing the research facilities and NCL-CSIR Pune for providing LCMS facilities. We also thankful to Mylan Laboratories Ltd.(Hyderabad), India. for providing us Boceprevir as gift sample.

\section{REFERENCES}

1. http://www.drugbank.ca/drugs/DB08873(date of browsing 02/05/2016)

2. European medicines agency,an agency of European union, assessment report, victrelis, 26 may 2011, procedure no,:EMEA/H/002332

3. Shiny. G. ,D.Satyavati. Development and validation of RP HPLC method for the analysis of Boceprevir and related impurities in bulk and pharmaceutical dosage forms, Indo American journal of pharmaceutical research, volume 5, issue 6,2015,2231-6876
4. Antonio D, Danilo A, et al., A UPLC-MS/MS method for the simultaneous plasma quantification of all isomeric forms of the new anti-HCV protease inhibitors boceprevir and telaprevir, Journal of pharmaceutical and biomedical analysis, 78-79, (2013), 217-223.

5. Zoubir D, Atherine F, Validation of a fast method for quantitative analysis of elvitegravir, raltegravir, maraviroc,etravirine, tenofovir, boceprevir and 10 other antiretroviral agents in human plasma samples with a new UPLC-MS/MS technology, Journal of pharmaceutical and biomedical analysis, 86, (2013), 100-111.

6. International Conference on Harmonization (ICH), Stability testing of new drug substances and products, Q1A (R2), (2003).

7. Madhav Shelke, S. S. Pekamwar. Stability indicating HPTLC method development and validation for estimation of ambroxol hydrochloride and levocetrizine dihydrochloride in combine syrup dosage form. Int. Res. J. Pharm. 2016;7(1):16-23 http://dx.doi.org/10.7897/22308407.0713

8. International Conference on Harmonization (ICH), Photo stability testing of new drug substances and products, Q1B.

9. International Conference on Harmonization (2005) ICH harmonised tripartite guideline Validation of analytical procedures: text and methodology Q2 (R1) ICH, Geneva, Nov (2005)

\section{Cite this article as:}

Mrinalini C. Damle, Sunny R. Salunke. Development and validation of stability-indicating HPLC method for determination of Boceprevir. Int. Res. J. Pharm. 2016;7(8):47$53 \mathrm{http}: / /$ dx.doi.org/10.7897/2230-8407.07895

Disclaimer: IRJP is solely owned by Moksha Publishing House - A non-profit publishing house, dedicated to publish quality research, while every effort has been taken to verify the accuracy of the content published in our Journal. IRJP cannot accept any responsibility or liability for the site content and articles published. The views expressed in articles by our contributing authors are not necessarily those of IRJP editor or editorial board members. 